\title{
CONTENTS
}

Acknowledgments vii

Foreword

Pamela Takayoshi xi

1 Re/Orienting Writing Studies: Thoughts on In(queer)y

William P. Banks, Matthew B. Cox, and Caroline Dadas

2 Making It Queer, Not Clear: Embracing Ambivalence and Failure as Queer Methodologies

Hillery Glasby 24

3 How (and Why) to Write Queer: A Failing, Impossible,

Contradictory Instruction Manual for Scholars of Writing Studies

Stacey Waite

42

4 Queering and Transing Quantitative Research

G Patterson 54

5 REDRES[ing] Rhetorica: A Methodological Proposal for Queering Cross-Cultural Rhetorical Studies

Chanon Adsanatham $\quad 75$

6 "Love in a Hall of Mirrors": Queer Historiography and the Unsettling In-Between

Jean Bessette 95

7 In/Fertility: Assembling a Queer Counterstory Methodology for Bodies of Health and Sexuality

Maria Novotny 112

8 Queering Networked Writing: A Sensory Authoethnography of Desire and Sensation on Grindr

Michael J. Faris 127 
9 Queer/ing Composition, the Digital Archive of Literacy Narratives, and Ways of Knowing

Deborah Kuzawa 150

10 Assessment Killjoys: Queering the Return for a Writing Studies Worldmaking Methodology

Nicole I. Caswell and Stephanie West-Puckett

11 On Queering Professional Writing

Caroline Dadas and Matthew B. Cox

About the Authors

209

Index 213 


\title{
RE/ORIENTING WRITING STUDIES Thoughts on In(queer)y
}

\author{
William P. Banks, Matthew B. Cox, and Caroline Dadas
}

Research is always about orientation, about how (and why and even to what extent) the researcher turns toward the objects, participants, or contexts of study. To stand in a classroom in front of twenty-five composition students is to stand in relation to others; usually, we stand there as their teachers, people charged with engaging these students in a host of activities intended to teach them about writing. But what if we're there not only as teachers but also as researchers, as teacher-researchers? Then while we might be oriented toward these students in the ways that a teacher typically is, we're also now oriented differently: we're seeing, being, engaging in more than one way, through more than one role. Our orientations as researchers mean we're in that space asking particular questions, looking for evidence to confirm or contradict working hypotheses; our being there as researchers means that we're operating on multiple cognitive levels, observing, yes, but also impacting that space through the ways our focus shifts.

The same would be true of any research site, whether that's the seemingly innocuous space of a nondescript room used for a focus group, the dusty and moldy space of a campus archive, or the bustling workplace we've chosen to observe as part of an office ethnography. When we enter a carefully chosen room to meet the five people who constitute a focus group, we engage that space and those people, we orient ourselves toward those people, as someone there to facilitate a focus group. We alter space by taking a seat near the video camera or the digital recorder; we ask the participants to move if they are not already sitting in the frame of the camera or near enough to the microphone to be heard and recorded. These orientations speak to our assumptions about who is in charge of collecting data, what counts as data, and which objects in the room have value. The same is true of the archive or the boardroom, or any other site where we show up and point ourselves toward 
objects of study. And we are also oriented from behind, as it were, by the discipline(s) we are part of, by the intellectual traditions and commonplaces out of which our inquiry questions have emerged-and to which we hope our own answers will contribute.

Experienced researchers know these things. We learned about these orientations in graduate seminars focused on research, or as we began to conduct our own research projects. But we also know that the methods and methodologies we studied and practiced in graduate school do not represent fully objective, ideology-free practices for studying objects, people, and spaces. Rather, each represents a way of orienting a researcher toward an object, a people, or a space. Where these practices-surveys, focus groups, observations, rhetorical analyses, and so forth-become commonplace, where they represent normative/ unquestioned activities or epistemologies, they demonstrate not only the ways that each has become an active method for orienting a researcher (and thus also preventing other orientations, other views from taking the foreground) but also how each has become a normative orientation for the field, a well-trodden path whose existence actively replicates itself from researcher to researcher, from discipline to discipline.

Reflecting on the "well-trodden path," Sara Ahmed (2006) writes in Queer Phenomenology, "Lines are both created by being followed and are followed by being created. The lines that direct us . . . are in this way performative: they depend on the repetition of norms and conventions, of routes and paths taken, but they are also created as an effect of this repetition" (16). These lines of motion are also lines of thought, of inquiry, of what is and is not permissible in the activities and frames that surround inquiry. In the intersections of the humanities and social sciences, where we tend to locate writing studies, these well-worn paths provide institutional and disciplinary validity; they become recognizable paths of inquiry and methods of discovery, and in their recognizability, their visibility as systematic processes, we take refuge in having developed (or co-opted) frames of empirical inquiry that lend our work certain kinds of validity as research. While one of the values of empirical research is that others can follow our methods for themselves and, ostensibly, validate our shared discoveries by reaching the same conclusions, Ahmed suggests that one reason other researchers find what we find is that they follow the line we established; our shared discoveries are as much about the lines we follow as they are about the data we collect or the methods we use to analyze them.

While writing studies has traditionally articulated research practices in terms of activities (methods) and frameworks (methodologies) 
(Harding 1987; Kirsch and Sullivan 1992), this bifurcated approach can make it difficult for scholars doing queer inquiry work to see how best to approach and understand their research. What counts as queer work, after all? Is it the subjects of our research or the contexts in which we conduct research that make our work queer? Is it the way we collect data or the way we frame our collection methods? Or does queer work involve a more nuanced understanding of these concepts, concepts that guide so much of the way our discipline responds to and frames the work we attempt to do?

This collection represents our attempt to address some of these questions and to challenge the heteronormative orientations that have guided inquiry in writing studies since its inception. The scholars included here work to unpack the complex ways that queer scholarship has impacted the field of writing studies by disrupting not only the subjects and contexts of inquiry but also the frames and activities (and activity systems) in which inquiry occurs. In her groundbreaking study of lesbian, gay, bisexual, and trans (LGBT) students in a writing classroom, Harriet Malinowitz (1995) asked the powerful question, "Which of our theories of writing don't explode when we consider their ramifications for lesbian and gay writers?" (39). The writers included in this collection turn that question toward research method/ologies to ask the field of writing studies, how might queer rhetorics and research "explode" our working theories of research methods and methodologies?

The writers included here also represent an emerging generation of scholars who are poised to address some of the key challenges that established scholars in the field have identified as kairotic for researchers in writing studies. For example, as part of introducing the recent collection Writing Studies Research in Practice: Methods and Methodologies, Gesa Kirsch (2012) identifies three specific challenges she thinks worthy of our collective attention. Writing researchers, she believes, should be

1. "adapting different research methods to diverse settings and reporting this research in genres that best reflect these methods" (xi);

2. engaging in "interactive, collaborative, reciprocal, mutually beneficial, nonhierarchical relations with research participants and their communities" (xii);

3. and recognizing that the "increasingly collaborative nature of research" means that "as writing studies has expanded its scope and breadth to include the rhetorical activities of those whose voices have been neglected, silenced, or rarely heard, scholars are showing a renewed concern for representing participants with respect, care, and complexity" (xiii-iv). 
These challenges are large and complex, but they also reflect a set of values central to the work of queer rhetorics and, we argue, to queer methods and methodologies. The writers included in this collection attempt to address these challenges in nuanced and rigorous ways, from engaging a diverse set of partners in research to playing with nontraditional genres in order to make their cases or represent their findings. Several authors also directly address the ways queer theories have helped them rethink language use so they can enact the sort of collaborative, nonhierarchical relationships that Kirsch believes our discipline should value. Through engaging new research sites and participants, and by framing and articulating their work through theories somewhat new to writing studies, these scholars offer insights into research practices in our discipline that we believe will help shape the next generation of writing researchers.

In this introduction, we attempt to situate the work that follows by articulating how these projects emerge at the intersections of queer rhetorics and queer method/ologies. This work, we believe, can serve to reorient the field of writing studies, not so that everyone is engaged in work around LGBT/Queer objects/texts, people, or contexts, but rather so that the discoveries and contributions of queer rhetorics and queer method/ologies can help us rethink the work of traditional data-collection methods and frames for inquiry. The projects and experiences reported on in this collection demonstrate how early-career researchers in writing studies have had to rethink our well-disciplined paths in order to do the work they need to do. We believe these pieces will be especially helpful to new and beginning researchers as they begin to think through the complex and often difficult practices of research.

\section{THINKING QUEERLY ABOUT IN(QUEER)Y}

Any book that attempts to explore queer theories, queer rhetorics, or anything we might want to label queer begins its work in a complicated, in fact quite "messy," place (Dadas 2016; Law 2004). For many, even most, researchers in writing studies, queer theories appear useful or applicable only if the research project involves LGBTQ people, objects / texts, and/or contexts. At the 2013 conference of the Council of Writing Program Administrators, for example, which took place in Savannah, Georgia, the theme for the three-day event was "Queering the Writing Program," and while there were three queer-focused plenary sessions, all delivered by queer-identified researchers who were engaged in queer-focused work, there was very little else about the conference that 
was queer. William remembers counting fewer than thirteen sessions in which it was clear from the title or session summary in the program that the papers from the session would actually engage queer work at all. More common was that the researchers who attended the event simply ignored the theme. Part of the reason for this disregard is that writing studies has mostly refused the "queer turn" that Jonathan Alexander and David Wallace suggest has occurred in our field over the last couple of decades (Alexander and Wallace 2009). They note that the emerging work of queer scholars in our field has produced a "better understanding of how heteronormativity operates in society at large, in our classrooms, and in the pages of our books and journals" (W301), and no doubt that's true. But as the WPA conference presenters demonstrated one after another, it's one thing to recognize heteronormativity and quite another to see how queer rhetorics shape, disrupt, or challenge our daily practices as writers, researchers, or, in this case, writing program administrators. One presenter admitted what we suspect was true of the majority in attendance: "I know this session doesn't really address the conference theme, but it turns out, we don't really know anything about queer theory, and we didn't want to embarrass ourselves by reading one or two articles and then trying to make our presentation connect to them." While the "queer turn" in the field for queer scholars has been about much more than simply adding gay or lesbian to our menu of identitarian concerns, much of the field, we suspect, has struggled to get past this sort of inclusionary mindset. In this section, we attempt to define queer rhetorics and queer methodologies such that the field of writing studies can better see how these theories of language and writing - about self and other, about agency and its failures-are foundational theories for anyone in writing studies to know and to engage. These theories do not merely explain how to include LGBT people in our discipline or our research, nor simply how to treat LGBT students or faculty; rather, these theories, like all theories, help us to see our work differently, to challenge what has come before, and to offer alternative ways of being in the world, regardless of sexual orientation.

\section{Queer Theory, Language Theory}

Early articulations of queer theory focused on two concepts that should have been both recognizable to and welcomed by writing studies scholars at the time: discourse and performativity. Borrowing heavily from the work of Michel Foucault, who posited that discourse, like power, is difficult to pin down in simplistic language structures, early queer theorists 
came to understand discourse as a method for both enacting power and disrupting it. Foucault (1988) writes, "We must not imagine a world of discourse divided between the dominant discourse and excluded discourse, or between the dominant discourse and the dominated one; but as a multiplicity of discursive elements that can come into play in various strategies" (122). Part of what queer scholars appreciated about Foucault's notions of discourse and power was that they made sense based on our own embodied experiences with language. Like other groups fighting for civil rights, queer people had experienced language hurled at them in rage so as dehumanize and belittle them, the same language they then flipped so those hurtful words, in queer spaces, became discourses of camaraderie, innuendo, and/or humor (Bergman 1993; Chauncey 1995; Cleto 1999; Meyers 1994). We're reminded of that infamously uncomfortable scene in Mart Crowley's The Boys in the Band (2008) in which Harold hurls the words Jew and fag around in ways intended to be both cruel and kind, aware of both how the world treats these two groups and what it means to play with those terms at parties like the one the characters in the play are attending. For Harold and the other characters at the party, language - and the party itself-becomes a type of resistance to the language outside that space. "Resistance," Annamarie Jagose (1996) writes, "is multiple and unstable; it coagulates at certain points, is dispersed across others, and circulates in discourse .. . [ that is] endlessly prolific and multivalent" (81). For many LGBTQ people, there is a felt sense, as much as a theoretical one, that one resistant method for maintaining our existence involves not being bludgeoned by languages intended to hurt us but pushing back, even in small ways, in order to maintain our own senses of self and community. Ultimately, this is a recognition that language itself is unstable and that within that instability, marginalized groups can attempt to assert agency.

Another attempt to find agency outside the spaces provided by normativity came about in queer theory's early adoption of performativity as a key concept. Performativity, like Foucauldian notions of discourse, foregrounds that which is "multiple and unstable" (Jagose 1996, 81), in this case referring to gender and sexuality. Early feminist and queer theorists (e.g., Diana Fuss, Luce Irigaray, Judith Butler), according to Jagose, began to recognize that woman represents "a regulatory fiction, whose deployment inadvertently reproduces those normative relations between sex, gender and desire that naturalize heterosexuality" (84). Woman-and man, girl, boy, lady, gentleman-doesn't represent a direct relationship between biological or anatomical demarcations of sex systems or sexual organs and language but rather a set of social, 
cultural, and (at times) biological beliefs that have solidified over time into concepts of gender that suggest individuals, based on anatomical sex, have essential and largely immutable behaviors, experiences, and mental functions because of that anatomy. Judith Butler (1993), however, recognized gender as "a ritualized production" (231) that never fully succeeds but that is always grounded in a language of its own undoing.

The practice by which gendering occurs, the embodying of norms, is a compulsory practice, a forcible production, but not for that reason fully determining. To the extent that gender is an assignment, it is an assignment which is never quite carried out according to expectations, whose addressee never quite inhabits the ideal $\mathrm{s} / \mathrm{he}$ is compelled to approximate. Moreover, this embodying is a repeated process. (231)

Key to queer theory's early articulations of gender performativity is the awareness that gender, like language, is systematically unstable, constantly in flux, endlessly repeatable. What this means for LGBTQ people, as well as those occupying and embracing more heteronormative bodies and experiences, is that these performatives are fundamentally antibinary (Bornstein 2013) and that they demonstrate our shared human experience of "being implicated in that which one opposes" (Butler 1993, 241): genders are known in relation to the many genders they are not. The same might be said for race, class, nationality, ethnicity, and so forth. The realization that language and identity are interwoven and interanimated means that any discipline focused on the study of language must engage theories and rhetorics grounded in such a realization. Likewise, our research practices must also be built out of such understandings.

What has this realization meant for writing studies so far? What might it mean for writing studies in the near future? For a field that trades in language study and language practice, it sometimes seems that queer theories have had little impact outside the study of language practices specific to LGBTQ people or to queer-as-identity scholarship. We're thinking here of Harriet Malinowitz's (1995) Textual Orientations: Lesbian and Gay Students and the Making of Discourse Communities, of course, but also Jonathan Alexander's shift from focusing exclusively on LGBTQ students to acknowledging a need for sexual literacy in Literacy, Sexuality, Pedagogy: Theory and Practice for Composition Studies (Alexander 2008), and Zan Gonçalves's (2006) exploration of queer students and rhetoric in Sexuality and the Politics of Ethos in the Writing Classroom. These important texts - as well as a host of articles in our field's major journals-helped to make queer texts, people, and contexts meaningful to the field of writing studies. At the same time, we fear that the field has walked away 
from these texts with the assumption that queer theories and queer rhetorics start and end with identity-oriented projects, and that if one is not studying LGBTQ students, texts, or contexts specifically, queer theories and queer rhetorics may have little to contribute to one's projects. While these authors would likely not identify their own research as only identity based, it seems to us that our discipline tends to take them up in just that way. That was certainly the feeling William had when he left the 2013 WPA conference. This shortsightedness, of course, is not the fault of these early queer projects, which served to open the door to connections between queer theories and writing studies; rather, we argue, it stems from a more fundamentally conservative strain in our field that has failed to recognize queer theories as important to our collective (and very broad) work with language and composition. Just as Martha Marinara, Jonathan Alexander, William P. Banks, and Samantha Blackman recognized that LGBTQ authors, texts, and topics only rarely have a place in our first-year composition readers-and if they do, they are often included as "issues" about which to argue (e.g., gays in the military, gay adoption) (Marinara et al. 2009) - more recently, Banks has been surveying graduate courses that serve as either (1) introductions to the field of writing studies and/or teaching writing or (2) courses on writing program administration and found that very few ( 5 percent or fewer) include texts that explicitly address issues of sexuality/queer theory and writing studies or writing program administration.

It seems to us that any set of theories that addresses language/ discourse should be given serious consideration in writing studies. The essays in this collection have all been informed by queer theories and queer rhetorics (which we might define as queer theory in action). Some of them (Adsanatham) demonstrate why we need to bring queer theories together with other cultural theories in order that each might be sharpened by the other. Other writers demonstrate how queer rhetorics can help us to rethink long-held assumptions about research methods central to writing studies like those used in historiography (Bessette), autoethnography (Faris), and writing assessment (Caswell and West-Puckett), while still others discover meaningful queer research practices in spaces that remain understudied like the Digital Archive of Literacy Narratives (Kuzawa) and fertility narratives (Novotny). Given this rich diversity of methods, methodologies, and research contexts, rather than ask, what has queer theory done for writing studies?, we might want to ask, what does this new generation of writing studies scholars see in queer theory that is helping them rethink the work of writing studies? 
Queer Rhetorics, Queer Method/ologies

Part of what we're seeing more recently is a shift from queer theory to queer rhetorics, a deliberate and thoughtful shift toward an actionoriented, rhetorically infused set of principles and practices informed by several decades of queer theoretical work. While innovative rhetorical and queer work is now happening in non-Western contexts like Thailand (Adsanatham, this collection) and among scholars working through indigenous traditions (Baca 2008; Driskill et al. 2011; Driskill 2016; Morgensen 2011; Smith 2011), it remains that the majority of work done in queer theory in its first thirty years has involved an evolution of primarily Western and European thought. No doubt, this represents a significant limitation for queer work writ large, one noted by a diverse set of scholars (Cohen 1995; Love 2009; Muñoz 1994; 2011) and one we acknowledge at greater length below. While we recognize this limitation, we also find that articulating a queer rhetoric, or queer rhetorics, must start somewhere. For the purposes of this collection, then, we situate queer rhetorics, and the method/ologies that emerge from or are influenced by them, in the tradition of the new rhetorics. For rhetorical scholars like Lloyd Bitzer (1968), rhetoric represents a "mode of altering reality" through the "creation of discourse which changes reality through the mediation of thought and action" (4). Rhetoric is the "the process of using language to organize experience and communicate it to others"; as such, it is both the "distinctive human activity and the 'science' concerned with understanding that activity," C. H. Knoblauch $(1985,29)$ tells us. And Krista Ratcliffe (2003) reminds us that rhetoric is "the study of how we use language and how language uses us."

Queer rhetorics, it seems to us, are fundamentally about the interconnections of language and reality, as well as the ways language mediates reality, alters reality-in short, the way language makes reality an option at all. But rather than assume a primarily ontological nature for language and reality, queer rhetorics begin with the assumption that critique-the calling out of language as language-represents an initial and important destabilization of meaning, not to prevent meaning or to pretend that meaning cannot be made but to ask why this meaning at this time and under these circumstances; these are fundamentally rhetorical questions:

To call a presupposition into question is not the same as doing away with it; rather it is to free it from its metaphysical lodgings in order to understand what political interests were secured in and by that metaphysical placing, and thereby to permit the term to occupy and to serve very different political aims. (Butler 1993, 30) 
Scholars engaged in queer rhetorics recognize the social nature of language, as well as the instability of language as both "social" and "natural." This queer engagement with language and reality, with objects and experiences, led Banks and Stephanie West-Puckett (2015) to identify three specific queer rhetorics that we want to bring up here as examples of how these rhetorics can impact both methods and methodologies for re/orienting writing studies: rhetorics of intentionality, forgetting, and failure. All three of these rhetorics originate in the embodied thinking of queer scholars and theorists and demonstrate what it might mean if writing studies took queer theories and queer rhetorics more seriously.

\section{Rhetorics of Intentionality}

By connecting queer phenomenologies (Ahmed 2006) and theories of trans identity and embodiment (Salamon 2011), Banks and West-Puckett (2015) demonstrate an important rhetorical practice among queer persons in which intention is (often) valued over outcome. For example, consider trans bodies that do not "pass" as the gender they may intend. No doubt, queer studies has a long and complex history of trying to understand "passing"-passing as straight, passing as gay or lesbian, passing as male or female (for both drag/cabaret performers and individuals who identify as trans). When we take up this conversation as part of a heteronormative rhetoric that values outcomes, that privileges the finished product over ongoing processes and practices, Banks and West-Puckett argue, we force queer bodies and experiences to "fail" by engaging them in a discourse that presupposes their inability to "pass," to occupy a body or performance in a system always already looking for them to fail. This discourse also assumes that the intended outcome is a heteronormative notion of gender or gender(ed) performance. They write,

Rather, the body becomes a complex and nuanced site of social and cultural negotiation that does not mean for a moment and then ceases to mean, or rather, does not mean a clear and determined meaning and then continues to mean that thing across times and contexts. . . By disrupting the ubiquitous binary of male/female, masculine/feminine, trans (and intersex) bodies call forth states of being that are neither and both. Trans bodies may intend states of being that succeed or fail in various contexts—or partially succeed or partially fail, as even that binary is ultimately flawed. These bodies tend to value intention over outcome.

Ultimately, Banks and West-Puckett argue that "part of what makes queer objects queer . . . is that they disrupt directionality, calling into question the paths that lead toward them, as well as away from them." 
In the context of this collection, we might ask, how does a queer rhetoric of intentionality shape methods of data collection or methodologies for understanding research purposes and contexts? For one, a queer rhetoric of intentionality would challenge the very foundation upon which the WPA Outcomes Statement is based; it would challenge the veracity and the validity of any rubric based on abstract and disembodied outcomes; and it might ask, both pedagogically and methodologically, what is the point of studying (evaluating, obsessing over) the products students create? When we consider how much writing studies research-the current micro-industry developing around threshold concepts and transfer, for example-is dependent on very particular notions of outcomes and seemingly observable data, any alternative rhetoric or methodology for studying writing that privileges intention over outcome would help us see our research from multiple and more nuanced positions. It might also help us think differently about what we mean by "outcomes" and "rubrics" (Caswell and West-Puckett, this collection). In the context of this collection, we also see how rhetorics of intentionality can be used to reframe digital tools (Faris, this collection) and to challenge both hetero- and homonormative assumptions about sexuality, digital spaces, and "hook-up" culture.

\section{Rhetorics of Failure}

Banks and West-Puckett (2015) also demonstrate, though obliquely, how a queer rhetoric of failure (Ahmed 2006; Halberstam 2011) could impact methods and methodologies in writing studies. In their CCCC talk, they focused primarily on the "C's the Day" game that has been part of welcoming newcomers to the conference over the last several years. In particular, they spoke at length about one of the prizes for "winning" the game, a small, hand-made artifact that came to be known as Sparklepony. While the story is too long to repeat here (deWinter and Vie 2014), part of what fascinated Banks and West-Puckett was the "failure" of the Sparklepony object as a piece of remix culture. They note that, as with the rhetoric of outcome (rather than intention), the field typically articulates remix in terms of success and failure, praising the student artifacts that "get it," that do something interesting and innovative with the artifacts they remix and ignoring in its studies examples of remix "failure," which leaves researchers to ask the question, what do we do with the failures? Sparklepony, they note, is only momentarily useful or interesting as a blazon at the conference; it means little outside that context. In fact, as they note, several academic blogs have mocked and 
poked fun at writing studies for its embrace of or interest in this "silly object” (Berlant 2009). Using Sparklepony and building on Halberstam (2011) in particular, Banks and West-Puckett question writing studies' neoliberal obsession with success and ponder what a queer rhetoric of failure might mean for our discipline.

Failure? What role can failure have in research, in which the goal is the discovery of truth or knowledge? To some extent, we might argue that Cheryl Glenn's (1995) now-classic study of Aspasia represents a rhetoric or methodology of failure. By looking at Aspasia's absences in the rhetorical canon, which grew out of Glenn's inability to find primary source materials connected to Aspasia, Glenn discovers a powerful way of understanding Aspasia's place and impact as an important rhetorical figure in ancient Greece. Of course, that isn't quite the same failure Banks and West-Puckett are engaging with. As Jack Halberstam (2011) explains, through a discussion of Barbara Ehrenreich's BrightSided, "While capitalism produces some people's success through other people's failure, the ideology of positive thinking insists that success depends only upon working hard and failure is always of your own doing" (3). Failure, Halberstam writes, might represent "knowledge from below" (11), a chance to eschew "being taken seriously" in order "to be frivolous, promiscuous, and irrelevant" (6). These are adjectives and experiences often linked to queer lives. And these are adjectives and experiences that seem to fly in the face of research and scholarship. Queerness-as-failure offers promise in those spaces where we make "a detour around the usual markers of accomplishment and satisfaction" (186), where we make use of promiscuous methods. Some researchers in this collection have begun to make use of failure-oriented methodologies as ways of interrogating a host of important discourses, like the medical rhetorics around in/fertility (Novotny), or even what it means to engage language queerly as part of designing research projects (Glasby; Waite). Still others (Caswell and West-Puckett) engage failure more significantly as a frame for rethinking writing assessment methodologies. After all, any theory of writing assessment that does not engage failure is a theory at best only half conceived. In the more quantitative/ mixed-methods areas of our research (Patterson), what might we do with the "long tails" of our data? Rather than construct these elements as "outliers," what if we embraced those moments of research failure? What might seeing the center of our data through its outliers do for helping us rethink what we are (really) searching for-and what we think we've found? 


\section{Rhetorics of Forgetting}

It's hard to imagine a practice more antithetical to historiography-or perhaps any research practice-than forgetting. So many scholars in writing studies have spent countless hours in archives, pouring over original documents, piecing together the histories of our field. Who would suggest we forget these things? While Banks and West-Puckett (2015) do not encourage us to "forget" anything in particular, they do demonstrate how "strategic forgetting" has been an important queer rhetorical practice and why we might want to engage such a practice more carefully and directly. They invite us to re/consider Jason Palmeri's (2012) Remixing Composition as a project that "demonstrates how orality and image have always been part of writing and writing studies" despite any number of essays in the field that tend to operate under the assumption that multimodality and remix are twenty-first-century inventions. Palmeri asks readers to ponder why writing studies has forgotten the richness of its multimodal history, even as his text demonstrates several reasons, not least of which is that so much of the multimodal work has happened at the pedagogical or classroom level or in textbooks rather than at the level of research. To extend Banks and West-Puckett's argument, we contend that rhetorics of forgetting tend to function in strategic ways and offer at least two ways of engaging with research. One method, with which we're quite familiar, is to mine the archives for lost stories, lost composers, lost teachers, and to tell their stories, to welcome these prodigal figures back into our rhetorical canon and demonstrate the richness they add to it. Another method, similar to Palmeri's history, might be to ask why certain elements of our disciplinary past have been forgotten: with Jim Ridolfo and Dànielle Nicole deVoss's notion of "rhetorical velocity" (Ridolfo and deVoss 2009) in mind, we might ask why certain tropes, conceits, or values picked up steam in writing studies and came to occupy a central place in our journals and books and why others have been (strategically) forgotten? How has forgetting those things been advantageous to certain researchers, composers, institutions? Why? What is it about these shameful figures that has made us forget?

In Feeling Backward: Loss and the Politics of Queer History, Heather Love (2009) demonstrates why queer scholars, or historians who seek to queer historiography, might want to engage that second type of forgetting project. Love notes that while "many queer critics take exception to the idea of a linear, triumphalist view of history, we are in practice deeply committed to the notion of progress; despite our reservations, we just cannot stop dreaming of a better life for queer people" (3). We recognize that writing studies can also find itself overly committed to 
triumphalist stories that might eventually save those sad women from the basement. Love encourages queer scholars in particular to pay attention to the "texts or figures that refuse to be redeemed" because they may serve to "disrupt not only the progress narrative of queer history but also our sense of queer identity in the present" (8-9). Queers are not the only bodies whose histories involve a long "association with failure, impossibility, and loss" (21). The pressure to redeem the past or to tell only stories that "rescue" forgotten figures threatens the present by offering it dangerously incomplete and inadequate stories of the past. In this collection, Jean Bessette encourages us to ask, "When we look for queerness in the archive, what exactly are we seeking?" Put more broadly, we might pose the following methodological questions for writing studies: When we look for $\mathrm{X}$, what are we strategically forgetting in order to keep $\mathrm{X}$ in focus? How could we acknowledge that tension in our work? Why might we need to forget $\mathrm{X}$ in order to discovery Y?

\section{EMBODYING IN(QUEER)Y}

These particular queer rhetorics-of intentionality, failure, and forgetting-are, of course, just a starting place for how we might engage queer rhetorics at the level of methodology, but each demonstrates how the embodied experiences and practices of queer lives have shaped theoretical questions that challenge the normative dimensions of our discipline. We're excited to showcase in this collection a set of essays by emerging and early-career queer scholars whose engagement with writing studies requires them to think differently about the methods and methodologies they were taught in graduate school. The authors in this collection make no claims that would suggest traditional methods of data collection are inherently flawed, nor do they suggest that only queer theories or queer rhetorics should dictate research agendas in writing studies. The essays in this collection do, however, encourage writing studies researchers to pay careful attention to the ways queer rhetorics and experiences have shaped our in(queer)y practices and our ways of engaging our discipline.

This collection begins by asking what queer might mean to researchers and whether or not it's possible to write (or study writing) from a queer/ed perspective. Hillery Glasby's "Making It Queer, Not Clear: Embracing Ambivalence and Failure as Queer Methodologies" picks up on both rhetorics of failure, briefly described above, and queer theories of language in order to posit important questions about how researchers 
construct their projects and their (embodied) relationships to those projects. Rather than remain yoked to notions of order, structure, and coherence, "what if composition functioned as a disordering agent?" (25). Similarly, Stacey Waite disrupts genre conventions in order to provide a "failing, impossible, contradictory" (43-48) list for queer writers. "How (and Why) to Write Queer" builds on past queer manifesto writing (Rhodes 2004) in order to explore the (dis)connections between queer writing practices and queer research practices. Perhaps one of the most challenging ways of posing the question about what it means to be/ act/write/research as queer is to ask how one might queer quantitative inquiry. G Patterson's "Queering and Transing Quantitative Research" takes up that challenge by exploring some of the more numbersoriented research methods in our field and unpacking some key questions around identifying and disidentifying data, designing surveys, and queering participant recruitment procedures.

After exploring definitions of queer and rethinking what it might mean to queer writing itself, two of our writers explore fairly traditional research topics and methodologies in writing studies (intercultural communication and historiography) in order to demonstrate why we might want more queer approaches to be part of the mix. In "REDRES[ing] Rhetorica: A Methodological Proposal for Queering Cross-Cultural Rhetorical Studies," Chanon Adsanatham highlights points of connectivity between queer theory and comparative rhetoric, particularly in their commitments to nonnormative thinking and interventions into the exclusion of the Other. He draws on both fields to develop a crosscultural heuristic he calls REDRES: recontemplating epistemology and knowledge across cultures; destabilizing what's normative and privileged; respecting and critically reevaluating historicity; embodying the ethics of hope and care; surfing incongruities as productive disruption. Through this heuristic, Adsanatham addresses the Eurocentric biases that often infiltrate rhetorical studies, offering an important contribution to queer rhetorical studies. Adsanatham grounds his theory in a case study of transnational Buddhist bodhisattva Kuanyin, demonstrating how past analyses of this figure have unfolded via normative lenses. Jean Bessette turns her attention toward the archives and our diverse histories in "Love in a Hall of Mirrors': Queer Historiography and the Unsettling In-Between" in order to explore questions of identity and what "counts" for researchers. Her contribution begins by exploring important binaries_-silence and speech, evidence and ephemera, truth and fiction-in order to argue for what she calls a "more spectral . . . understanding of history writing" (97). What are the stories our archives 
tell us when we disrupt some of these binaries? And what, to borrow from Love (2009), do our stories forget?

Stories and storytelling, of course, have been central to much of writing studies, not just our histories. From case studies and ethnographies to teacher action research, from pedagogical inquiry to the significance they play in our administrative theory and scholarship, stories are a major part of how we communicate our experience and research. In "In/Fertility as Counter/Story: Assembling a Queer Counterstory Methodology for Bodies of Health and Sexuality," Maria Novotny explores her own experiences with in/fertility, as well as those of other women and couples, in order to construct a counterstory through "queer assemblage" methods. This project, Novotny notes, can be useful to writing studies researchers but also to professionals in other spaces, such as medical clinics and hospitals. Similarly, Michael Faris explores the limits of storytelling as part of his autoethnographic project "Queering Networked Writing: A Sensory Autoethnography of Desire and Sensation on Grindr." Faris argues that writing studies has taken up sexuality in identitarian and discursive ways, largely ignoring sex acts and sensuality (and by extension other embodied, if messy, experiences). Faris's autoethnographic approach to studying his own activity on the digital app Grindr offers innovative methods for tracing desire and affect. In doing so, this contribution stands as a rare example of queer scholarship in writing studies that focuses on sex, not simply the abstract sexuality. The implications of Faris's study are wide reaching, complicating the notion that rhetoric is preceded by identification. Faris asks whether rhetorical interactions might be based on sensuality and desire rather than identity, particularly in digital environments. Ultimately, Faris disrupts normative epistemological attachments by attending to sensory and affective ways of knowing and connecting. In "Queer/ing Composition, the Digital Archives of Literacy Narratives, and Ways of Knowing," Deborah Kuzawa turns to the stories of the DALN to demonstrate how a queer methodology can be applied to contexts apart from those having to do with sexuality or gender. Kuzawa illustrates how queer methodologies and methods can help illuminate the ways systems of power operate in relation to literacy and knowledge. Kuzawa argues that through the queer method of "surfing binaries," the DALN resists the kind of binaristic thinking common to archives, troubling the discourses of academic/personal, restriction/openness, and expert/novice. The DALN's openness, which resists clear-cut definition of what counts as literacy, stands as a queer way of making meaning, allowing those who contribute to the archive to offer their own 
definitions of what counts as literacy. Through this analysis of the DALN, Kuzawa argues that a queer lens can help make visible how archives and other repositories of knowledge function as living systems that exist in a constant state of flux.

This collection ends on a perhaps unexpected but certainly queer note: validating failure. In particular, Nicole Caswell and Stephanie West-Puckett rely on queer notions of failure in order to sketch out a methodology for conducting and engaging with writing assessment. In "Assessment Killjoys: Queering the Return for a Writing Studies Worldmaking Methodology," Caswell and West-Puckett encourage us "to see good writing less as a monolithic set of traits and more as a dynamic assemblage of cultural values, one that resists hegemonic notions of knowing, doing, being, and expressing." Their chapter highlights a host of failure-oriented practices built on a queer validity inquiry (QVI) methodology in order to show writing studies the significant and exciting possibilities that exist on the other side of success. In as much as writing assessment can seem like an odd place to encourage or look for failure, so too can professional writing contexts seem antithetical to the work we're meant to be doing. However, Caroline Dadas and Matthew Cox explore just that in their chapter, "On Queering Professional Writing." While scholars such as Angela Haas (2012) have argued for increased attention to cultural rhetorics within professional writing, Dadas and Cox argue that the field has not given much attention to queer contexts or methodological frames. Based on an analysis of journal articles and conference presentations published in the last five years, Dadas and Cox contend that queer methodologies are not well represented in the field. They then argue that queer methodologies can enhance professional writing studies by calling attention to normative binaries often implied in professional writing contexts, such as success/failure. Increased use of queer frames for professional writing work can counter the hypernormativity or hypernormativizing rhetorics we often see at play in the field.

\section{CONCLUSION: HOW TO USE THIS BOOK}

It may seem strange, given the antinormative drive that animates so much of queer work, and we hope this collection, to end this introduction by offering a user's guide or even to suggest one particular method for how best to use this book. But this isn't that sort of "how-to." This how-to is also a when-to, a where-to, as well as a what-if and a why-bother-to. Those of us who have pulled this collection together hope the projects ignite in readers an awareness that what may seem like boundaries and 
limitations to research are simply the starting points for a researcher's most interesting projects, questions, and entanglements. Now that the editors of this collection teach courses in research methods, we see in our own undergraduate and graduate students how easy it is for beginning researchers to find a method of data collection that feels comfortable, or one that seems to have clear boundaries, and then try to shove their projects into it. It's not all that different from the first-year writer who learned forms (e.g., compare and contrast, classification and division) and then talks about their projects based on those forms rather than their topics, interests, or inquiry questions. For some, this way of structuring knowledge making can feel comfortable and assuring; amidst the chaos of what might be, at least we know we're doing a "case study," even if we're not sure why or what that really means.

This collection of essays, whose authors at times make use of familiar forms or concepts like autoethnography, narrative/story, writing assessment, case study, and surveys, is not designed or arranged by such categories. Nor does it lend itself to being read cover to cover. The authors use overlapping theories in different ways, and they explore a number of different types of research and research contexts to do so. As such, we envision this collection as one that supplements any number of the excellent methods collections in the field, including Katrina Powell and Pamela Takayoshi's Practicing Research in Writing Studies: Reflexive and Ethically Responsible Research (Powell and Takayoshi 2012) and Lee Nickoson and Mary P. Sheridan's Writing Studies Research in Practice: Methods and Methodologies (Nickoson and Sheridan 2012), as well as more thematically focused texts like Jacqueline Jones Royster and Gesa Kirsch's Feminist Rhetorical Practices: New Horizons for Rhetoric, Composition, and Literacy Studies (Royster and Kirsch 2012) and Eileen Schell and K. J. Rawson's Rhetorica in Motion: Feminist Rhetorical Methods and Methodologies (Schell and Rawson 2010). Texts like these, as well as John Creswell's general overview of research methods, Research Design: Qualitative, Quantitative, and Mixed-Methods Approaches (Creswell 2013), provide important contexts for research, contexts the contributions from this collect help unpack, disrupt, or extend. We encourage readers to supplement the more traditional texts with the essays from this collection, as well as essays and texts that address some critical absences from our own collection, texts like Linda T. Smith's Decolonizing Methodologies: Research and Indigenous Peoples (Smith 2012), Chela Sandoval's Methodology of the Oppressed (Sandoval 2000), and Margaret Kovach's Indigenous Methodologies: Characteristics, Conversations, and Contexts (Kovach 2010). 
In mentioning these texts, we also want to encourage readers to move the work of this collection forward. Earlier, we acknowledged the long history of Western thought that produced queer theory, as well as our most common definitions of rhetoric, and how much our own collection builds on that work. We recognize that this somewhat singular history creates a limitation to our collection; we hope writing studies recognizes this limitation as well and is encouraging more diverse scholars and scholarship. We believe our collection works well to encourage more diverse projects in writing studies, and we hope the readers of this collection will take up the work that was not yet available in writing studies when we solicited manuscripts for this collection. We know that, moving forward, this sort of complex and exciting research will come to define writing studies as one of the more progressive disciplines in the academy.

\section{REFERENCES}

Ahmed, Sara. 2006. Queer Phenomenology: Orientations, Objects, Others. Durham, NC: Duke University Press. https://doi.org/10.1215/9780822388074.

Alexander, Jonathan. 2008. Literacy, Sexuality, Pedagogy: Theory and Practice for Composition Studies. Logan: Utah State University Press. https://doi.org/10.2307/j.ctt4cgqkw.

Alexander, Jonathan, and David Wallace. 2009. "The Queer Turn in Composition Studies." College Composition and Communication 61 (1): W300-W320.

Baca, Damien. 2008. Mestiz@ Scripts, Digital Migrations, and the Territories of Writing. New York: Palgrave Macmillan. https://doi.org/10.1057/9780230612570.

Banks, William P., and Stephanie West-Puckett. 2015. "Against Re/Production: Trans Theory, Digital Objects, and a Queer Paradigm For Remix." Conference on College Composition and Communication, March 20. Tampa, FL.

Bergman, David, ed. 1993. Camp Grounds: Style And Homosexuality. Amherst: University of Massachusetts Press.

Berlant, Lauren. 2009. The Queen of America Goes to Washington City: Essays on Sex and Citizenship. Durham, NC: Duke University Press.

Bitzer, Lloyd. 1968. "The Rhetorical Situation." Philosophy Eै Rhetoric 1:1-14.

Bornstein, Kate. 2013. A Queer and Present Danger: The True Story of a Nice Jewish Boy Who Joins the Church of Scientology, and Leaves Twelve Years Later to Become the Lovely Lady She Is Today. Boston, MA: Beacon.

Butler, Judith. 1993. Bodies That Matter: On the Discursive Limits of Sex. New York: Routledge.

Chauncey, George. 1995. Gay New York: Gender, Urban Culture, and the Making of the Gay Male World, 1890-1940. New York: Basic Books.

Cleto, Fabio, ed. 1999. Camp: Queer Aesthetics and the Performing Subject, A Reader. Ann Arbor: University Of Michigan Press.

Cohen, Cathy. 1997. "Punks, Bulldaggers, and Welfare Queens: The Radical Potential of Queer Politics." GLQ: A Journal of Lesbian and Gay Studies 3 (4): 437-65. https://doi .org/10.1215/10642684-3-4-437.

Creswell, John. 2013. Research Design: Qualitative, Quantitative, and Mixed-Methods Approaches. 4th ed. Thousand Oaks, CA: SAGE.

Crowley, Mart. 2008. The Boys in the Band: 40th Anniversary Edition. New York: Alyson Books. 
Dadas, Caroline. 2016. "Messy Methods: Queer Methodological Approaches to Researching Social Media." Computers and Composition 40 (1): 60-72. https://doi.org/10.1016/j .compcom.2016.03.007.

Driskill, Qwo-Li. 2016. Asegi Stories: Cherokee Queer and Two-Spirit Memory. Tucson: University of Arizona Press.

Driskill, Qwo-Li, Chris Finley, Brian Joseph Gilley, and Laura Scott Morgensen. 2011. Queer Indigenous Studies: Critical Interventions in Theory, Politics and Literature. Tucson: University of Arizona Press.

Foucault, Michel. 1988. "Power and Sex." In Politics, Philosophy, Culture: Interview and Other Writings, 1977-84. Translated by David J. Parent. Edited by Lawrence D. Kristzman, 110-24. New York: Routledge.

Glenn, Cheryl. 1995. "Remapping Rhetorical Territory." Rhetoric Review 13 (2): 287-303.

Gonçalves, Zan. 2006. Sexuality and the Politics of Ethos in the Writing Classroom. Carbondale: Southern Illinois University Press.

Haas, Angela. 2012. "Race, Rhetoric, and Technology: A Case Study of Decolonial Technical Communication Theory, Methodology, and Pedagogy." Journal of Business and Technical Communication 26 (3): 277-310. https://doi.org/10.1177/1050651912439539.

Halberstam, Jack. 2011. The Queer Art of Failure. Durham, NC: Duke University Press. https://doi.org/10.1215/9780822394358.

Harding, Sandra. 1987. "Introduction: Is There a Feminist Method?" In Feminism and Methodology, edited by Sandra Harding, 1-14. Bloomington: Indiana University Press.

Jagose, Annamarie. 1996. Queer Theory: An Introduction. New York: New York University Press.

Kirsch, Gesa. E. 2012. "Forward: New Methodological Challenges for Writing Studies." In Writing Studies Research in Practice: Methods and Methodologies, edited by Lee Nickoson and Mary P. Sheridan, xi-xvi. Carbondale: Southern Illinois University Press.

Kirsch, Gesa, and Patricia A. Sullivan. 1992. Methods and Methodology in Composition Research. Carbondale: Southern Illinois University Press.

Knoblauch, C. H. 1985. "Modern Rhetorical Theory and Its Future Directions." In Perspectives on Research and Scholarship in Composition, edited by Ben W. McClellan and Timothy R. Donovan, 26-44. New York: MLA.

Kovach, Margaret. 2010. Indigenous Methodologies: Characteristics, Conversations, and Contexts. Toronto: University of Toronto Press.

Law, John. 2004. After Method: Mess in Social Science Research. New York: Routledge.

Love, Heather. 2009. Feeling Backwards: Loss and the Politics of Queer History. Cambridge, MA: Harvard University Press.

Malinowitz, Harriet. 1995. Textual Orientations: Lesbian and Gay Students and the Making of Discourse Communities. Portsmouth, NH: Heinemann-Boynton/Cook.

Marinara, Martha, Jonathan Alexander, William P. Banks, and Samantha Blackman. 2009. "Cruising Composition Texts: Negotiating Sexual Difference in First-Year Readers." College Composition and Communication 61 (2): 269-96.

Meyers, Moe, ed. 1994. The Politics and Poetics of Camp. New York: Routledge.

Morgensen, Scott Lauria. 2011. "Unsettling Queer Politics: Whitman Non-Natives Learn from Two-Spirit Organizing?” In Queer Indigenous Studies: Critical Interventions in Theory, Politics and Literature, edited by Qwo-li Driskill, Chris Finley, Brian Joseph Gilley, and Scott Lauria Morgensen, 132-51. Tucson: University of Arizona Press

Muñoz, José Esteban. 1994. Disidentifications: Queers of Color and the Performance of Politics. Minneapolis: University of Minnesota Press.

Muñoz, José Esteban. 2011. Cruising Utopia: The Then and There of Queer Futurity. New York: New York University Press.

Nickoson, Lee, and Mary P. Sheridan, eds. 2012. Writing Studies Research in Practice: Methods and Methodologies. Carbondale: Southern Illinois University Press. 
Palmeri, Jason. 2012. Remixing Composition: A History of Multimodal Writing Pedagogy. Carbondale: Southern Illinois University Press.

Powell, Katrina, and Pamela Takayoshi, eds. 2012. Practicing Researching Writing Studies: Reflexive and Ethically Responsible Research. New York: Hampton.

Ratcliffe, Krista. 2003. "The Current State of Composition Scholar/Teachers: Is Rhetoric Gone or Just Hiding Out?" enculturation 5(1). http://enculturation.net/5_1/ratcliffe .html.

Ridolfo, Jim, and Dànielle Nicole DeVoss. 2009. "Composing for Recomposition: Rhetorical Velocity and Delivery." Kairos: A Journal of Rhetoric, Technology, and Pedagogy 13 (2). http://kairos.technorhetoric.net/13.2/topoi/ridolfo_devoss/.

Rhodes, Jacqueline. 2004. "Homo Origo: The Queertext Manifesto." Computers and Composition 21 (3): 385-88. https://doi.org/10.1016/j.compcom.2004.05.001.

Royster, Jacqueline Jones, and Gesa Kirsch. 2012. Feminist Rhetorical Practices: New Horizons for Rhetoric, Composition, and Literacy Studies. Carbondale: Southern Illinois University Press.

Salamon, Gayle. 2011. Assuming a Body: Transgender and Rhetorics of Materiality. New York: Columbia University Press.

Sandoval, Chela. 2000. Methodology of the Oppressed. Minneapolis: University of Minnesota Press.

Schell, Eileen, and K. J. Rawson. 2010. Rhetorica in Motion: Feminist Rhetorical Methods and Methodologies. Pittsburgh, PA: University of Pittsburgh Press. https://doi.org/10.2307/ j.ctt5vkff8.

Smith, Andrea. 2011. "Queer Theory and Native Studies: The Heteronormativity of Settler Colonialism.” In Queer Indigenous Studies: Critical Interventions in Theory, Politics and Literature, edited by Qwo-li Driskill, Chris Finley, Brian Joseph Gilley, and Scott Lauria Morgensen, 43-65. Tucson: University of Arizona Press.

Smith, Linda T. 2012. Decolonizing Methodologies: Research and Indigenous Peoples. London: Zed Books.

deWinter, Jennifer, and Stephanie Vie. 2015. "Sparklegate: Gamification, Academic Gravitas, and the Infantalization of Play." Kairos: A Journal of Rhetoric, Technology, and Pedagogy 20 (1). http://kairos.technorhetoric.net/20.1/topoi/dewinter-vie/. 